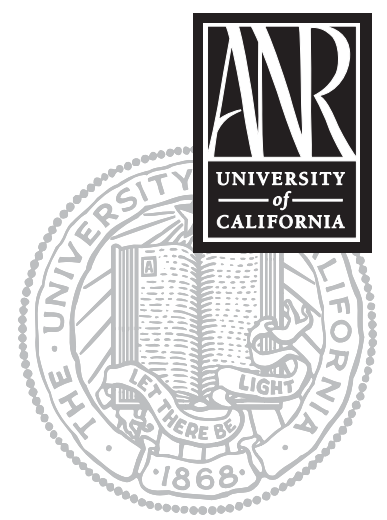

UNIVERSITY OF CALIFORNIA

Division of Agriculture and Natural Resources http://anrcatalog.ucdavis.edu

\title{
Feral Poultry: How to
}

\section{Construct a User-Friendly Trap}

FRANCINE A. BRADLEY, UC Cooperative Extension Poultry Specialist, Department of Animal Science, University of California, Davis; BRIGID A. MCCREA, Postdoctoral employee, Department of Animal Science, University of California, Davis; P. V. TEPUS, City of Palos Verdes Estates

Feral poultry are birds such as chickens, ducks, geese, turkeys, and peafowl that live on their own, often ranging across public and private properties without human management. Problems with feral poultry are on the increase. Home owners and city workers who try to eliminate them are often unsuccessful in their attempts to trap the birds. Traps designed for live-trapping of mammals, though they may be humane and heavily advertised, seldom work well with poultry.

\section{TRAPPING FERAL POULTRY}

A live-catch trap for feral poultry can be built with readily available materials. The instructions are simple and the cost is reasonable. The trap is a plastic barrier fencing enclosure operated by manually raising and lowering a trap door. The basic design allows for changes in size based on the number of birds to be trapped and the area available for erecting the trap. Live-trapped feral poultry should not be released; they must be confined and managed (see "Use of the Trap," on the following page.)

\section{EQUIPMENT}

For the trap perimeter and top:

- eight 6-foot-tall lightweight steel T-posts

- one 7-foot-tall lightweight steel T-post

- two rolls of 4-foot-tall plastic barrier fencing

- two 100-packs of 8-inch cable ties

- five 6-packs of 7-inch skewer pegs or tent stakes

- post hole driver

For the trap door:

- four 10-foot lengths of 1/2-inch PVC pipe

- four 1/2-inch PVC elbow fittings

- two 1/2-inch PVC T-fittings

- one pulley

- 50 feet of rope (or more, as needed)

\section{WHERE TO ERECT THE TRAP}

For greatest success, erect the trap in an area currently frequented by feral poultry. For most homeowners, this will be the back yard. For municipalities, trouble spots may include parks or other public settings.

Unfortunately, some people do not appreciate the damage that feral poultry can do to private property and to the habitat of native species and may attempt to sabotage trapping in an effort to protect the poultry. Therefore, siting traps on private property, shielded from public view, is often the most effective strategy. 
Figure 1. Perimeter of trap.

\section{TRAP CONSTRUCTION}

Place four 6-foot T-posts along two parallel lines that are 10 feet apart (fig. 1). Using a post hole driver, pound each T-post in to the ground until it is stable. Roll the plastic barrier fencing around the outside of the T-posts on three sides to form the trap's perimeter, leaving an open space for the door. Secure the barrier fencing to the T-posts using the cable ties. Secure the bottom of the barrier fencing to the ground using the skewer pegs or tent stakes. The number of stakes needed depends on the type of poultry being trapped and their ability to escape under the fence bottom. Peafowl and geese are powerful and will attempt to squeeze under the fencing. Therefore, more stakes may be needed when trapping these birds.

Center the 7-foot T-post in the trap. Use the second roll of 4-foot barrier fencing for the trap's cover (fig. 2). This can be done by joining lengths of the fencing with zip ties to make sections wide enough to cover the entire trap. If barrier fencing can be found in widths of 12 feet or more, covering the trap will be easier. Do not pull the covering tight; allow it to be draped. A flexible cover protects birds from injury if they fly up while in the trap. Use cable ties to attach the cover to the edges of the barrier fencing. Bunch the center of the cover loosely around the center T-post.
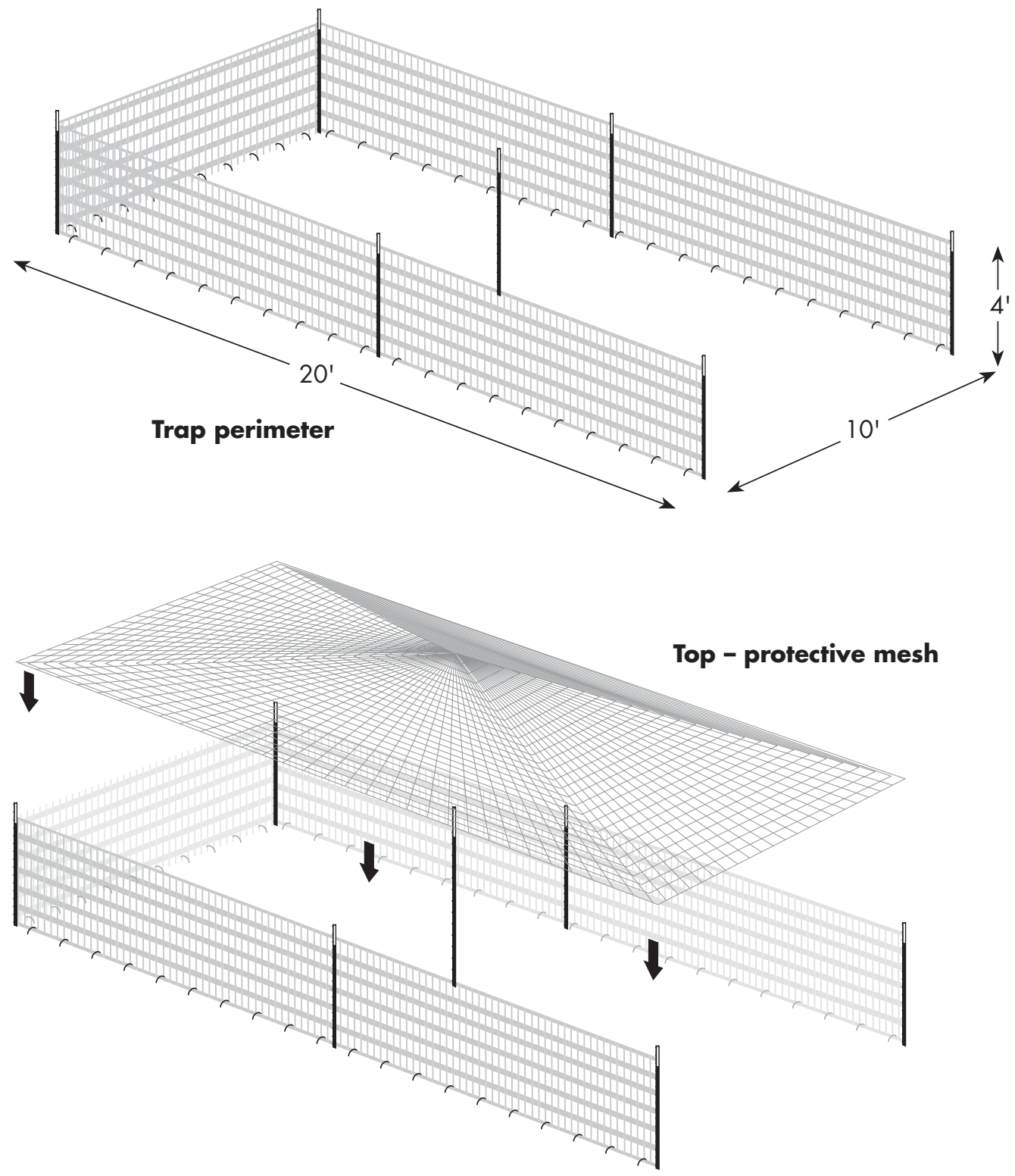

Figure 2. Cover of trap. 
To make the trap door, cut three 4-foot lengths and four 5-foot lengths of PVC pipe. Use the elbow fittings to form the corners of the door. Use the T-fittings to join the 5-foot sections of the top and bottom to the 4-foot sides and center brace. Attach barrier fencing to the PVC pipe door frame with cable ties. Attach the door to the cage frame with cable ties at the notches on the T-posts. Tie one end of the rope to the bottom center T-fitting and pipe to complete the trap door.

\section{USE OF THE TRAP}

The rope attached to the trap door should be run to a remote area using the pulley (or pulleys, as needed; see fig. 3). Depending on the location, this location might be an elevated deck, the back door of a home, or some other convenient hidden area. The trapper must be able to observe the activity around the trap without frightening the birds. Once the trap is assembled, bait the back of the trap. Suitable bait can be whatever the feral poultry have been enjoying in the area up to this point, such as dry pet birdseed, garden fruit, vegetables, bedding plants, and so on. Allow the poultry to become accustomed to entering the trap, feeding, and leaving.

Before live-trapping feral poultry, establish a plan for relocating them. Trapped feral poultry should not be released; they must be appropriately confined and managed. Releasing the birds in other areas is stressful to the birds and inhumane, as well as socially and environmentally inappropriate. Contact local animal control agencies and humane societies to see if they can take the trapped birds. Have suitable carriers, such as molded plastic pet carriers, ready for transporting trapped birds. Move the birds in a vehicle that is well ventilated and provides protection from the elements. Plan to move the birds during a time of day when extremes in temperature can be avoided.

Figure 3. Trap door.

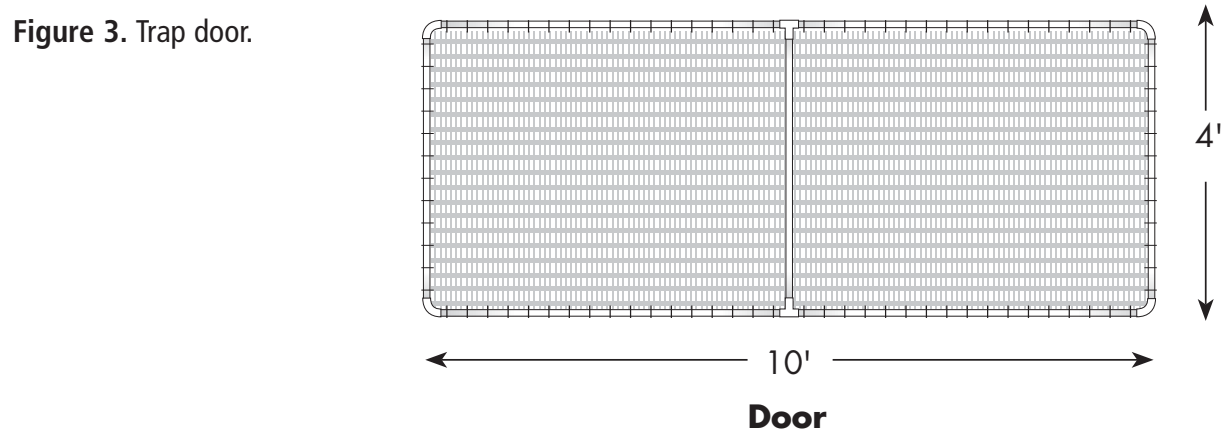

Completed trap - side view

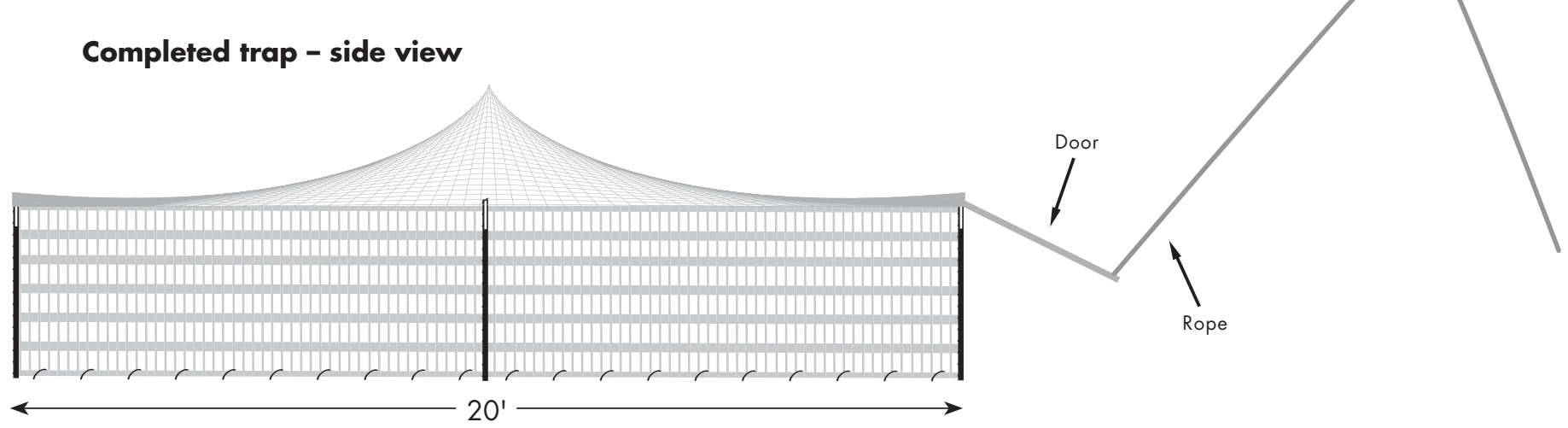


When a good number of birds are in the trap, lower the trap door using the rope and pulley. A small-scale trapping operation is best done by two people: one person to enter the trap and catch the birds and a second person to watch the trap door. Catch a feral chicken by grabbing its legs. Carry it with its weight supported in the palm of the hand and the fingers of the same hand through the bird's legs, thus restricting its movement. Catch a peafowl by slowly maneuvering the bird next to the side of the trap. With the bird parallel to your body, grasp the bird's near leg and the far wing. Grasp the wing at the point where it attaches to the body of the bird. Lift the bird straight up using both hands. Adult peafowl have powerful wings; take care to handle them without injuring the bird or yourself.

Once caught, place the feral poultry in pet carriers or other suitable containers. An alternative is to put a T-shirt over the bird's head with the head sticking out of the neck opening and the shirt covering the bird's body; then wrap the T-shirt with masking tape to secure it and restrict the bird's movement.

Live-catch feral poultry traps require little equipment, are easy to construct, are relatively inexpensive, and do not harm the birds. The size of the trap can easily be adapted to specific circumstances.

\section{FOR FURTHER INFORMATION}

To order or obtain ANR publications and other products, visit the ANR Communication Services online catalog at http://anrcatalog.ucdavis.edu. You can also place orders by mail, phone, or FAX, or request a printed catalog of our products from

University of California

Agriculture and Natural Resources

Communication Services

6701 San Pablo Avenue, 2nd Floor

Oakland, California 94608-1239

Telephone 1-800-994-8849

(510) 642-2431

FAX (510) 643-5470

E-mail:danrcs@ucdavis.edu

This publication has been anonymously peer reviewed for technical accuracy by University of California scientists and other qualified professionals. This review process was managed by the ANR Associate Editor for Animal, Avian, and Aquaculture Sciences.

Publication 8284

ISBN-13: 978-1-60107-528-4

(C)2008 The Regents of the University of California

Division of Agriculture and Natural Resources

All rights reserved.

No part of this publication may be reproduced, stored in a retrieval system, or transmitted, in any form or by any means, electronic, mechanical, photocopying, recording, or otherwise, without the written permission of the publisher and the authors. 
The University of California prohibits discrimination or harassment of any person on the basis of race, color, national origin, religion, sex, gender identity, pregnancy (including childbirth, and medical conditions related to pregnancy or childbirth), physical or mental disability, medical condition (cancer-related or genetic characteristics), ancestry, marital status, age, sexual orientation, citizenship, or status as a covered veteran (covered veterans are special disabled veterans, recently separated veterans, Vietnam era veterans, or any other veterans who served on active duty during a war or in a campaign or expedition for which a campaign badge has been authorized) in any of its programs or activities. University policy is intended to be consistent with the provisions of applicable State and Federal laws.

Inquiries regarding the University's nondiscrimination policies may be directed to the Affirmative Action/Staff Personnel Services Director, University of California, Agriculture and Natural Resources, 1111 Franklin Street, $6^{\text {th }}$ Floor, Oakland, CA 94607-5201, (510) 987-0096. For information about ordering this publication, telephone 1-800-994-8849.

pr-3/08-SB/RW 